\title{
Microfinance in Russian Regions: Lending to Entrepreneurs in 2018
}

\author{
Iuliia S. Pinkovetskaia ${ }^{1, *}$, Anton V. Lebedev ${ }^{2}$, Mikhail A. Rozhkov ${ }^{2}$, Diego Felipe Arbelaez Campillo ${ }^{3}$, \\ Magda Julissa Rojas Bahamon ${ }^{4}$ \\ ${ }^{1}$ Department of the Economic Analysis and State Management, Institute of Economics and Business, Ulyanovsk State University, \\ Ulyanovsk, 432000, Russia \\ ${ }^{2}$ Department of the English Language for Professional Communication, National Research Ogarev Mordovia State University, Saransk, \\ 430005, Russia \\ ${ }^{3}$ CEO Editorial Primmate SAS, Research Group Languages, Representations and Education, University Amazonia, Florencia, \\ Colombia \\ ${ }^{4}$ Educational Institution Jorge Eliecer Gaitán, University Amazonia, Florencia, Colombia
}

Received August 3, 2021; Revised September 27, 2021; Accepted October 17, 2021

\section{Cite This Paper in the following Citation Styles}

(a): [1] Iuliia S. Pinkovetskaia, Anton V. Lebedev, Mikhail A. Rozhkov, Diego Felipe Arbelaez Campillo, Magda Julissa Rojas Bahamon, "Microfinance in Russian Regions: Lending to Entrepreneurs in 2018," Universal Journal of Accounting and Finance, Vol. 9, No. 6, pp. 1258 - 1264, 2021. DOI: 10.13189/ujaf.2021.090605.

(b): Iuliia S. Pinkovetskaia, Anton V. Lebedev, Mikhail A. Rozhkov, Diego Felipe Arbelaez Campillo, Magda Julissa Rojas Bahamon (2021). Microfinance in Russian Regions: Lending to Entrepreneurs in 2018. Universal Journal of Accounting and Finance, 9(6), 1258 - 1264. DOI: 10.13189/ujaf.2021.090605.

Copyright $\bigcirc 2021$ by authors, all rights reserved. Authors agree that this article remains permanently open access under the terms of the Creative Commons Attribution License 4.0 International License

\begin{abstract}
The purpose of the research is to assess the indicators describing the activities of microfinance lending systems for entrepreneurs in Russian regions. Our study uses official statistics on the quantity and total amount of microloans provided for entrepreneurs in all regions of Russia in 2018. The paper deals with the following relative indicators: the number of microfinance loans per 1000 entrepreneurs, the number of microloans per one region resident, the number of microloans per entrepreneur, and the average value of one microloan. Our study provides an assessment of these indicators for all regions of the country, determines their average values and intervals of change, typical for most regions and identifies regions with large and low values of these indicators. Methodology used in the paper and the developed tools can be used in further scientific works devoted to microfinance. The research results can be applied by state and regional bodies in the process of formation and implementation of measures that improve financing of the business sector. The developed models can be referred to when determining the needs for entrepreneurs' microfinance in regions where the entrepreneurial sector is not discussed. The data obtained can be used in the process of teaching bachelor and master students at universities.
\end{abstract}

Keywords Microfinance, Financial Resources, Microloans, Entrepreneurs, Entrepreneurship Support

\section{Introduction}

Banks are the main source of lending to enterprises and organizations in developed and developing countries. However, these institutions rarely provide financial services for entrepreneurs owning small businesses.

Obtaining bank loans by entrepreneurs is problematic for the following reasons $[1,2,3,4]$ :

- the lack of credit history for many entrepreneurs;

- banks experiencing difficulties in collecting sufficient information on the activities of specific entrepreneurs and, accordingly, monitoring their financial conditions;

- banks high requirements to the availability of fixed assets for entrepreneurs, which can be pledged as collateral for loans;

- high level of entrepreneurial risks.

In addition, banks, with relatively small amounts of 
financing for entrepreneurs, incur higher operating and administrative costs compared to large organizations [5]. Entrepreneurs, in turn, find it difficult to obtain complete information about financial lending programs that exist in each of the banks.

The above-stated reasons significantly reduce the availability of loans for entrepreneurs in comparison with large enterprises. Banking organizations prefer to consider larger firms as consumers of funds, which seem to be more preferable, especially according to the first and fourth factors. The research [6] shows that banks charge high interest rates and large collateral for entrepreneurs. The recent crisis events have aggravated the stated issue, and many banking institutions have practically stopped providing loans for entrepreneurs.

Therefore, entrepreneurs are currently experiencing serious problems in attracting the necessary funds and are forced to use the services of microfinance companies. Microfinance, as indicated in [7], developed after 1970 as one of the lending instruments on the periphery of financial markets. To date, microfinance institutions provide incentives for entrepreneurs with constrained (or even limited) access to traditional methods of obtaining credit using the opportunities provided by banks. Without microfinance organizations these entrepreneurs could only use funds borrowed from family members or acquaintances as sources of financing. This would reduce the opportunities for the development of entrepreneurial activity, and would often lead to its total termination [8].

It is necessary to pay attention to the fact that microfinance organizations, along with solving financial problems of entrepreneurs, also create prerequisites for ensuring social effect in modern national economies [9]. By supporting entrepreneurs, they provide an increase in the level of employment of the economically active population, increase the income of entrepreneurs and their employees and, accordingly, improve the quality of life of people involved in entrepreneurship [1, 10]. The social attractiveness of microfinancing offers an inflow of funds to the relevant organizations providing these organizations with high authority in the financial markets [11].

Although nowadays microfinance has led to the creation of strong credit institutions focused on entrepreneurs in a number of countries, further development of this financing tool seems to be relevant, in particular, on the basis of expanding access for all who need additional funds [12].

At the moment, the entrepreneurial sector is of great importance in the development of the Russian economy. In 2018, 5.29 million enterprises and entrepreneurs belonged to small and medium businesses, and the total number of all employed in the entrepreneurial sector reached 19.16 million people, that is, more than $25 \%$ of the economically active population of the country. Entrepreneurs account for about a quarter of the gross domestic product [13]. It can be concluded from these data that entrepreneurs create new jobs and produce a large volume of goods, as well as provide a significant number of services for enterprises and individuals.

Due to the great importance of entrepreneurship, it seems relevant to provide both relevant legal entities and individual entrepreneurs with stable and affordable financing.

When conducting this research, we considered the proposals on the study of the important problem of entrepreneurs' access to the most effective types of financing stated in the scientific literature $[14,15]$.

The purpose of the article is to assess the indicators describing the activities of microfinance lending systems for entrepreneurs in the regions of Russia. The study solves the tasks of determining the average values of the microfinance activity indicators and identifying regions with high and low values of indicators.

\section{Review of Literature}

In the twenty-first century, microfinance acts as a viable alternative for entrepreneurs experiencing difficulties in obtaining loans from banks. It stimulates the development of entrepreneurship by facilitating the process of obtaining funds for the operation and development of businesses. The difference between microfinance and bank lending is the provision of small loans to entrepreneurs [16].

As the accumulated experience shows, the legal forms of microfinance organizations are different. In modern countries, there are many different types of formal and informal institutions, which include government organizations, cooperatives, credit associations, non-profit organizations, non-bank financial institutions [17].

According to the author of the article [18], about five hundred million entrepreneurs are in need of microloans every year. At the same time, there is a certain deficit of such loans, which allows us to conclude that there is a certain potential for further growth in microfinance.

It is interesting to note that there have been relatively few (500 to 700) microfinance institutions in Europe in recent decades. This situation was due to the peculiarities of state regulation of their activities. In particular, in Germany and Serbia, these institutions can issue loans only in cooperation with banks. In Greece, microfinance can be carried out by institutions with very high equity capital [19].

The issues of microfinance lending have had certain observation in scientific research literature. Nyikos and Gabor [20] studied the experience of microfinance accumulated by the EU countries. Financing of microloans is provided both from national sources and from the relevant funds of the EU. The Chinese experience of microfinance is presented in the article by Wang [21]. The author concludes that entrepreneurs with 
high financial risk and low productivity are more likely to seek microfinance. At the same time, the provision of loans takes into account the existing achievements in the introduction of innovations into products, as well as the high efficiency of management activities. The final report [22], following a workshop on microfinance activities in the Black Sea region, discusses various options for this activity. The experience of Eastern European countries in supporting entrepreneurs is presented. The work of Shankar [23] deals with the experience of microfinance in the countries of South Asia. It is shown that in India, Bangladesh and Pakistan, the provision of microloans to entrepreneurs is carried out sporadically due to the weak development of the respective microcredit organizations. The article by Nahamya et al. [24] describes the socioeconomic characteristics that influence the parameters of microfinance in Uganda. These characteristics are as follows: the location of the entrepreneurs, the gender of the owner, the level of education, the age of the business, the assets before the loan, and the availability of collateral. The study by Al-Absi [25] examines the impact of microloan components on the development of small business, such as collateral, loan amount, its duration and interest rate in Yemen.

Russian economic studies consider various directions of the state policy in the field of financing the entrepreneurial sector; however, the issues of providing microloans to entrepreneurs in Russia were reflected only in some of them. Thus, Sheina [26] in her article shows the number of microloans issued for entrepreneurs in the Sverdlovsk region for the period of 2009-2014. The work of Zhigas and Petrova [27] deals with the specifics of the activities of microfinance organizations in Russia, presents the analysis of the dynamics of the number of microfinance organizations for the period of 2011-2016. The article by Korolev [28] lists the advantages of microloan activities, namely, taking into account the characteristics of each borrower, the selection of a profitable option for issuing a loan and interest on it. This article also highlights the disadvantages of microloan programs - high operating costs, the need for skilled labor, and significant interest rates. The analysis of the implementation of microfinance within the framework of state support for entrepreneurship in 2010 is given in the work of Maltseva [29]. The experience of microfinance activities in the Oryol region is provided by Kalabukhina [30]. The study describes how to ensure the repayment of loans, the procedure for calculating the borrower's payments, taking into account his/her financial activities. Shaposhnikov [31] examines the issues of lending to legal entities and draws attention to the drawback of the limitation in the number of microloans for entrepreneurs. In the article published by Akulich and Nalgiev [32], the authors consider the features of issuing microloans to entrepreneurs in the Magadan region. The study analyzes the role of a large microfinance organization in this area. Charaeva [33] looks into the statistical information on the activities of Russian microfinance organizations and formulates proposals on the prospects for improving their activities in Russia. Grabskaya et al. [34] defines the essence and role of microfinance organizations as sources of additional funds for entrepreneurs.

The review of previous studies on microcredit programs shows that no analysis of the regional aspects of this activity in Russia has yet been carried out.

\section{Materials and Methods}

As noted above, various microfinance programs are widely used in developed and developing countries to address the problem of sustainable financing for entrepreneurs. In Russia, this activity is organized in accordance with the Federal law of July 2, 2010 No. 151-FZ [35], according to which a microfinance organization is a legal entity carrying out the relevant activity. That is, such an organization issues microloans for legal entities and individual entrepreneurs.

State microfinance programs are typically run by specialized organizations that are usually managed by the government or regional authorities. They facilitate access to financing by providing loans for entrepreneurs.

Our study examines the following relative indicators characterizing the performance of microfinance systems in all regions of Russia in 2018 (the last period included in statistical reports):

- the number of microfinance loans per 1000 entrepreneurs;

- the sum of microloans per 1 inhabitant;

- the sum of microloans per 1 entrepreneur;

- the average value of one microloan.

Using relative indicators allows comparing them across different regions of the country and identifying regions with high and low values.

In our work we used the official statistical information given in the appendix to the above-mentioned collection of Rosstat of Russia [36].

During the research, the following hypotheses were tested:

- hypothesis 1 - microloan systems for entrepreneurs have become widespread in all regions of Russia;

- hypothesis 2 - there is a significant differentiation in values of the four considered indicators by regions.

To test the first hypothesis, an analysis of the initial empirical data for the regions of Russia was carried out. At the same time, the presence of microfinance organizations in each of the regions in 2018 and the volume of loans issued by them were determined. To test the second hypothesis, an analysis of the variation in the values each of the indicators was carried out. 
To assess the values of the indicators, mathematical models (normal distribution functions) were used. These functions allow us to provide unbiased values for each characteristic under consideration. The description of the methodology for using these functions is demonstrated in article [37]. On the basis of the developed functions, the average values of all four indicators can be established, the ranges in which they change, and also the regions of the country with high and low values of indicators can be identified. The boundaries of the indicated ranges for the majority $(68 \%)$ of national economies can be calculated based on the mean values of indicators and deviations. The minimum value corresponding to the lower limit of the range is defined as the difference between the corresponding mean values and standard deviations. The value of the upper limit is determined as their sum.

\section{Results of the Calculation Experiment}

Official statistical information indicates that in 2018 the total number of operating microfinance organizations was 27,421 . The total amount of microloans issued by them for entrepreneurs reached more than 23 billion rubles.

In the course of the simulation experiment, we have developed economic and mathematical models (corresponding to the Gaussian distribution law), characterizing the regional distribution of the four previously indicated indicators. The corresponding functions $(y)$ showing the distribution of the values of the four indicators $(x)$ across all regions of Russia are given below:

- the number of microfinance loans per 1000 entrepreneurs

$$
y_{1}\left(x_{1}\right)=\frac{413,67}{5,84 \times \sqrt{2 \pi}} \cdot e^{\frac{-\left(x_{1}-8,13\right)^{2}}{2 \times 5,84 \times 5,84}}
$$

- the sum of microloans per 1 inhabitant, rubles

$$
y_{2}\left(x_{2}\right)=\frac{8633,86}{131,83 \times \sqrt{2 \pi}} \cdot e^{\frac{-\left(x_{2}-203,84\right)^{2}}{2 \times 131,83 \times 131,83}}
$$

the sum of microloans per 1 entrepreneur, thousand rubles

$y_{3}\left(x_{3}\right)=\frac{370,13}{5,64 \times \sqrt{2 \pi}} \cdot e^{\frac{-\left(x_{3}-7,33\right)^{2}}{2 \times 5,64 \times 5,64}} ;$

- the mean value of one microloan, thousand rubles

$$
y_{4}\left(x_{4}\right)=\frac{20085,71}{284,60 \times \sqrt{2 \pi}} \cdot e^{\frac{-\left(x_{4}-888,13\right)^{2}}{2 \times 284,60 \times 284,60}} \text {. }
$$

To analyze functions (1) - (4), the Kolmogorov-Smirnov, Pearson and Shapiro-Vilk criteria were used, showing how well these functions approximate empirical data. At the same time, the calculated statistics were compared with the tabular ones. The analysis showed the high quality of each of the four functions.

As mentioned earlier, the developed functions allow us to establish the mean values of the indicators of the microfinance organizations activity and the intervals of their change that have developed in the regions. They are shown in the table: the mean values are in column 2, the ranges of change in the values of indicators for most regions are in column 3 .

Table 1. Indicators characterizing the activity of microloan organizations

\begin{tabular}{|c|c|c|c|}
\hline Name of indicator & $\begin{array}{c}\text { Mean value of an } \\
\text { indicator }\end{array}$ & $\begin{array}{c}\text { Indicators' change interval for } \\
\text { most regions }\end{array}$ & Level of variation, \% \\
\hline 1 & 2 & 3 & 4 \\
\hline $\begin{array}{c}\text { the number of microfinance loans per 1000 } \\
\text { entrepreneurs }\end{array}$ & 8,13 & $2,29-13,97$ & 65 \\
\hline the sum of microloans per 1 inhabitant, rubles. & 203,84 & $72,01-335,67$ & 77 \\
\hline $\begin{array}{c}\text { the sum of microloans per 1 entrepreneur, } \\
\text { thousand rubles. }\end{array}$ & 7,33 & $1,69-12,97$ & 32 \\
\hline $\begin{array}{c}\text { the number of microfinance loans per 1000 } \\
\text { entrepreneurs }\end{array}$ & 888,13 & $603,53-1172,73$ & \\
\hline
\end{tabular}

Source: The table is compiled on the basis of functions (1)-(4). 


\section{Discussion}

The results obtained allow us to establish the average values of the indicators, as well as to determine the regions with high and low values of each of the four indicators that were assessed during the study.

Column 2 of Table 1 shows the regional average of the number of active microfinance loans per 1000 entrepreneurs, which was slightly more than 8 . That is, in the regions of Russia, on average, only $0.8 \%$ of the entrepreneurs used such loans in 2018. Table 2, column 2 lists the regions for which the indicator value is higher than 14.0. Accordingly, in column 3 of this table, regions are indicated with an indicator value less than 2.3.

The microloans per 1 inhabitant of the region amounted to almost 204 rubles in 2018. At the same time, for most regions, the corresponding value of the indicator was in the range from 72 to 336 rubles. Column 2 of Table 2 shows regions with values greater than the upper limit of the range, and column 3 - regions with values smaller than the lower limit of the range.

The sum of microloans per entrepreneur was 7.33 thousand rubles. Similarly, the following lines of Table 2 show the lists of regions corresponding to high and low values of the indicator of microloans attributable to entrepreneurs.

The average size of one microloan reached 0.89 million rubles. In 2018, in most regions, this indicator was in the range of 0.6-1.2 million rubles. Columns 2 and 3 of Table 2 provide lists of regions with relatively high and low rates.

The data presented in column 4 of Table 1 show high levels of variation each of the indicators (more than 30\%). Thus, the second hypothesis was confirmed.

The analysis of statistical data showed that microfinance organizations worked in all regions in 2018. The minimum number of such organizations was observed in the Republic of Khakassia (9 organizations), the maximum number (1732 organizations) was in the Republic of Udmurtia. Microloans for entrepreneurs were issued in all Russian regions without exception. Thus, the first hypothesis was confirmed.

The research results are of theoretical and practical importance. The proposed methodology and the resulting models can be applied to subsequent scientific works devoted to microfinance for entrepreneurs. They can be used for the development of programs of assistance to the entrepreneurial sector by state structures, in particular, for determining the needs for support to entrepreneurs in regions where the entrepreneurial sector is not developed.

The data obtained can be used in the process of teaching bachelor and master students at universities and other higher institutions. The research results are of interest to financial and credit organizations. Further research can be conducted to assess the gender and sectoral characteristics of microloan entrepreneurs.

Table 2. High and low indicator values of microfinance organizations performance by regions

\begin{tabular}{|c|c|c|}
\hline Name of indicator & Regions with high indicator values & Regions with low indicator values \\
\hline 1 & 2 & 3 \\
\hline $\begin{array}{l}\text { the number of microfinance } \\
\text { loans per } 1000 \text { entrepreneurs }\end{array}$ & $\begin{array}{c}\text { Bryansk Region, Novgorod Region, Kirov Region, } \\
\text { Oryol Region, Republic of Karachay-Cherkessia, } \\
\text { Republic of Tyva, Republic of Altai, Republic of } \\
\text { Buryatia, Republic of Udmurtia, Republic of } \\
\text { Mordovia, Kamchatka Territory, Trans-Baikal } \\
\text { Territory }\end{array}$ & $\begin{array}{l}\text { Omsk Region, Samara Region, Chelyabinsk } \\
\text { Region, Moscow Region, Volgograd Region, } \\
\text { Tambov Region, Nizhny Novgorod Region, } \\
\text { Republic of Khakassia, Republic of Karelia }\end{array}$ \\
\hline $\begin{array}{l}\text { the sum of microloans per } 1 \\
\text { inhabitant }\end{array}$ & $\begin{array}{c}\text { Bryansk Region, Vologda Region, Novgorod Region, } \\
\text { Sakhalin Region, Kirov Region, Oryol Region, Altai } \\
\text { Republic, Republic of Buryatia, Republic of } \\
\text { Udmurtia, Republic of Mordovia, Khabarovsk } \\
\text { Territory, Kamchatka Territory, Trans-Baikal } \\
\text { Territory }\end{array}$ & $\begin{array}{c}\text { Omsk Region, Ivanovo Region, Samara } \\
\text { Region, Chelyabinsk Region, Moscow Region, } \\
\text { Tambov Region, Kemerovo Region, Nizhny } \\
\text { Novgorod Region, Republic of Khakassia, } \\
\text { Komi Republic }\end{array}$ \\
\hline $\begin{array}{c}\text { the sum of microloans per } 1 \\
\text { entrepreneur }\end{array}$ & $\begin{array}{c}\text { Bryansk region, Oryol region, Kirov region, } \\
\text { Novgorod region, Republic of Sakha, Republic of } \\
\text { Adygea, Republic of Buryatia, Republic of Dagestan, } \\
\text { Republic of Udmurtia, Republic of Mordovia, } \\
\text { Chechen Republic, Trans-Baikal Territory, } \\
\text { Kamchatka Territory }\end{array}$ & $\begin{array}{l}\text { Samara Region, Chelyabinsk Region, Moscow } \\
\text { Region, Omsk Region, Ivanovo Region, Nizhny } \\
\text { Novgorod Region, Republic of Khakassia }\end{array}$ \\
\hline $\begin{array}{l}\text { the mean value of one } \\
\text { microloan }\end{array}$ & $\begin{array}{c}\text { Kursk Region, Moscow Region, Samara Region, } \\
\text { Chelyabinsk Region, Sakhalin Region, Omsk } \\
\text { Region, Smolensk Region, Ryazan Region, Tambov } \\
\text { Region, Oryol Region, Murmansk Region, Republic } \\
\text { of Khakassia, city of Sevastopol }\end{array}$ & $\begin{array}{l}\text { Ivanovskaya oblast, Smolensk oblast, } \\
\text { Murmansk oblast, Tomsk oblast, Leningrad } \\
\text { oblast, Irkutsk oblast, Kabardino-Balkarian } \\
\text { republic, Komi republic, Ingushetia republic, } \\
\text { Tyva republic, Perm krai }\end{array}$ \\
\hline
\end{tabular}

Source: The table is compiled on the basis of functions (1) - (4). 


\section{Conclusions}

The conducted research has achieved its goal. Its results have significant novelty and originality:

- the methodological approach to assessing the performance of the microfinance loan system in the regions of Russia has been proposed;

- the economic and mathematical models that describe the existing levels of the four indicators considered in the article have been developed;

- the average values and indicators' change intervals by most regions, describing the activities of state support for entrepreneurs on the basis of microfinance have been determined;

- it has been proved that microloan programs for entrepreneurs have become widespread in all regions of Russia;

- it has been justified that currently there are significant differences in the values of each of the four indicators under consideration by region.

- the regions with high and low values of each of the four indicators have been identified.

\section{REFERENCES}

[1] Afsheen Abrar. The impact of financial and social performance of microfinance institutions on lending interest rate: A cross-country evidence. Cogent Business \& Management. No. 6:1. 1540072. P. 1-21. 2019. DOI: 10.1080/23311975.2018.1540072.

[2] H. Tunahan, A.S. Dizkirici. Evaluating the Credit Guarantee Fund (Kgf) of Turkey as a Partial Guarantee Program in the Light of International Practicest. International Journal of Business and Social Science. Vol. 3(10). P. 79-92. 2012.

[3] I.S. Pinkovetskaia, E.A. Sverdlikova, A.V. Lebedev. Estimating entrepreneurial risk in Russian small and medium-sized enterprises. The Journal of Contemporary Issues in Business and Government. Vol. 25(1). P. 30-43. 2019.

[4] N.V. Trusova , L.V. Melnyk, Z.S. Shilo, O.S. Prystemskyi. Credit-Investment Activity of Banks of the Ukraine: Financial Globalization, Risks, Stabilization. Universal Journal of Accounting and Finance. Vol. 9(3). P. 450-468. 2021. DOI: 10.13189/ujaf.2021.090320.

[5] D. Kent, M.T. Dacin. Bankers at the gate: Microfinance and the high cost of borrowed logics. Journal of Business Venturing. Vol. 28(6). P. 759-773. 2013.

[6] T. Baas, M. Schrooten. Relationship banking and SMEs: A theoretical analysis. Small Business Economics. Vol. 27(2-3). P. 127-137. 2006.

[7] J.D. Von Pischke. Microfinance in Developing Countries. In: Carr, J. H. y Tong, Z. Y. (Eds) Replicating Microfinance in the United States. Woodrow Wilson Center Press. Washington. P. 65-96. 2002.
[8] M.M. Soares, Melo Sobrinho A. D. de. Opapel do Banco Central do Brasil e a importancia do cooperativismo de credito. DF. BCB. Brasilia. 2008.

[9] A. Alam, R.S. Nizam, M.T. Hidayat. The Role of Islamic Microfinance Institution in Empowering Indonesian Fishing Communities. Universal Journal of Accounting and Finance. Vol. 9(2). P. 178-183. 2021. DOI: 10.13189/ujaf.2021.090205.

[10] C. Serrano-Cinca, B. Gutierrez-Nieto. Microfinance, the long tail and mission drift. International Business Review. Vol. 23(1). P. 181-194. 2014

[11] J. Schicks. Over-indebtedness in microfinance - an empirical analysis of related factors on the borrower level. World Development. Vol. 54(C). P. 301-324. 2014.

[12] L. Dokulilova, K. Janda, P. Zetek. Sustainability of Microfinance Institutions in Financial Crisis. European Financial and Accounting Journal. Vol. 4. No. 2. P. 7-33. 2009.

[13] Statistical Book. Small and medium entrepreneurship in Russia. Rosstat. Moscow. 2019.

[14] A. Nuwagaba. Micro Financing Of Small and Medium Enterprises (Smes) In Zambia. International Journal of Business and Management Invention. Vol. 4. No. 8. P. 48-56. 2015.

[15] V. Kovačević, M. Beslac, D. Vukosavljević, R. Grozdanić Microfinancing in SMEs Development, Evidence from Serbia. JWE. No. 1-2. P. 92-116. 2014.

[16] S. Quayes. Depth of outreach and financial sustainability of microfinance institutions. Applied Economics. Vol. 44(26). P. 3421-3433. 2012. DOI: 10.1080/00036846.2011.57701 6.

[17] L. Daher, E. Le Saout. Microfinance and financial performance. Strategic Change. Vol. 22(1-2). P. 31-45. 2013. DOI: $10.1002 /$ jsc. 1920 .

[18] Y. Bayar. Future of microfinance in the light of recent crises in major microfinance markets. Social Business. Vol. 3(3). P. 243-249. 2013. DOI: 10.1362/204440813X1377872913 4363.

[19] A. Cozarenco. Microfinance Institutions and Banks in Europe: The story to date. CEB Working Paper 15/027. Centre Emile Bernheim, and Centre for European Research in Microfinance (CERMi). 2015.

[20] G. Nyikos, S. Gabor. Microfinance and access to finance of SMEs. EU cohesion policy in Eastern and Southern Europe: taking stock and drawing lessons for the future. Conference. Innovation Management, Entrepreneurship and Sustainability (IMES). Praha. 2018.

[21] X. Wang. The Impact of Microfinance on the Development of Small and Medium Enterprises: The Case of Taizhou, China. 2013. Available at: https://econ.jhu.edu/wp-content/ uploads/sites/27/2013/07/SeniorThesis_Xitian_WANG.pdf

[22] Final workshop report on "Microfinance for SMEs in the Black sea economic cooperation region" organized by Organization of the black sea economic cooperation (BSEC) and Konrad-Adenauer-Stiftung (KAS) Edited by Dr. Antal Szabo. 12-15 November. Bucharest. Romania. 2014. 
[23] S. Shankar. Bridging the "Missing Middle" between Microfinance and Small and Medium-Sized Enterprise Finance in South Asia. ADBI Working Paper 587. Asian Development Bank Institute. Tokyo. 2016.

[24] W. Nahamya, M. Ajanga, M. Omeke, N. Tumwine, M. Nasinyama. The impact of microfinance service delivery on the growth of SMEs in Uganda. International Journal of Economics, Commerce and Management United Kingdom. Vol. III. No. 5. 2015.

[25] Al-Absi A. Ala'a. Impact of Microcredit in Microfinance Banks on Small Business Spread in Yemen (Case Study of Sana'a, Yemen). International Journal of Business and Management Invention. Vol. 5. No. 11. P. 14-29. 2016.

[26] E.G. Sheina. Improving the microfinance system as a factor in the development of small and medium-sized entrepreneurship. Russian Electronic Scientific Journal. Vol. 8(14). P. 73-77. 2014.

[27] M.G. Zhigas, I.A. Petrova. Trends of microfinance in Russia. Baikal Research Journal. Vol. 9. No. 2. 2018.

[28] D.A. Korolev. Prospects for the development of microfinance for small businesses in Russia. Society: politics, economics, law. No. 2. P. 54-58. 2013.

[29] O.V. Maltseva. Microfinance as a tool for supporting small businesses. State and municipal administration. Scientific notes of SKAGS. No. 1. P. 153-160. 2011.

[30] M.V. Kalabukhina. Analysis of support for small and medium-sized businesses in the Orel region. Scientific notes of ORELGIET. Vol. 4(16). P. 82-87. 2016.
[31] I. G. Shaposhnikov. Development of non-bank credit institutions in Russia. Basic research. Vol. 8(5). P. 1153-1157. 2014.

[32] O.V. Akulich, H.T. Nalgiev. The role of microfinance organizations in lending to small and medium-sized businesses in the Magadan region. JUVENIS SCIENTIA. No. 5. P. 4-7. 2018.

[33] M.V. Charaeva. The realities and prospects of using microfinance in the context of the development of small and medium-sized businesses. Financial research. Vol. 2(63). P. 42-50. 2019.

[34] Y.I. Grabskaya, S.I. Antonov, Y.S. Vdovina. Microfinance organizations as a promising tool for attracting financing for small and medium-sized businesses in Russia. International Youth Symposium on Management, Economics and Finance: a collection of scientific articles. Institute of Management, Economics and Finance of KFU. P. 69-71. 2016.

[35] On microfinance activities and microfinance organizations: Federal Law 2 July 2010. No. 151-FZ.

[36] Appendix to the collection "Small and medium-sized entrepreneurship in Russia" (information in the context of the subjects of the Russian Federation). Rosstat. Moscow. 2019.

[37] I. Pinkovetskaia, V. Slepova. Estimation of Fixed Capital Investment in SMEs: the Existing Differentiation in the Russian Federation. Business Systems Research. Vol. 9(1). P. 65-78. 2018 